TABLE II-Plasma hormone levels (geometric means) in groups of men before and after vasectomy. Standard errors of mean log ${ }_{10}$ concentrations are given in parentheses.

\begin{tabular}{|c|c|c|c|c|c|c|c|c|c|}
\hline \multirow{2}{*}{ Hormone } & \multirow{2}{*}{$\begin{array}{c}\text { No of } \\
\text { estimations }\end{array}$} & \multirow{2}{*}{$\begin{array}{l}\text { Pre-vasectomy } \\
\text { group }\end{array}$} & \multicolumn{5}{|c|}{$\begin{array}{l}\text { Post-vasectomy groups } \\
\text { Time since operation (years) }\end{array}$} & \multicolumn{2}{|c|}{ Variance ratio* } \\
\hline & & & $<1$ & $1-2$ & $3-4$ & $\geqslant 5$ & All times & $\begin{array}{l}\text { All five } \\
\text { groups }\end{array}$ & $\begin{array}{l}\text { Before vasec- } \\
\text { tomy } v \text { after } \\
\text { vasectomy }\end{array}$ \\
\hline 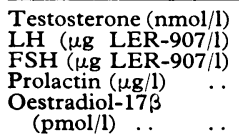 & $\begin{array}{l}277 \\
269 \\
266 \\
258 \\
276\end{array}$ & $\begin{array}{r}9 \cdot 1(0.015) \\
57.9(0.020) \\
87.1(0.025) \\
12.4(0.033) \\
96.8(0.017)\end{array}$ & $\begin{array}{r}11.4(0.028) \\
59.0(0.036) \\
83.2(0.038) \\
9.4(0.063) \\
93.7(0.032)\end{array}$ & $\begin{array}{r}9.8(0.023) \\
56.4(0.024) \\
94.0(0.026) \\
12.6(0.038) \\
87.4(0.020)\end{array}$ & $\begin{array}{r}9.9(0.035) \\
57.5(0.035) \\
98.9(0.026) \\
11.4(0.054) \\
94.6(0.025)\end{array}$ & $\begin{array}{r}9.4(0.031) \\
60.7(0.031) \\
95.3(0.034) \\
15.1(0.048) \\
92.4(0.027)\end{array}$ & $\begin{array}{l}10.0(0.015) \\
58.2(0.015) \\
93.8(0.015) \\
12.3(0.025) \\
91.4(0.013)\end{array}$ & $\begin{array}{l}1.73 \\
0.18 \\
0.86 \\
1.84 \\
0.69\end{array}$ & $\begin{array}{l}3.06 \\
0.002 \\
1.30 \\
0.005 \\
1.45\end{array}$ \\
\hline
\end{tabular}

* To achieve $5 \%$ level of significance variance ratio would have to exceed 2.40 for comparison of five groups and 3.87 for comparison of two groups.

Conversion: SI to traditional units-Testosterone: 1 nmol $/ 1 \approx 28 \cdot 8 \mathrm{ng} / 100 \mathrm{ml}$. Oestradiol-17 $\beta$ : $1 \mathrm{pmol} / 1 \approx 0 \cdot 272 \mathrm{pg} / \mathrm{ml}$.

specimens were taken in the evening, when testosterone concentrations are generally lower than during the day. ${ }^{6}$ ?

Previous studies of testicular endocrine function at one month ${ }^{8}$ and up to three months ${ }^{9}$ after vasectomy have not shown significant changes. Smith $e t \mathrm{al}^{10}$ followed men for up to a year after the operation, but over a quarter of their subjects were either excluded or untraced. They reported a significant increase in both mean plasma testosterone and LH after vasectomy; in our study mean testosterone concentrations (though not $\mathrm{LH}$ levels) were slightly higher in men who had undergone vasectomy.

If testosterone levels really are higher after vasectomy several explanations are possible. Firstly, there may be an increased frequency of intercourse after the operation, and this may affect testosterone secretion. ${ }^{11}$ Secondly, psychological stress may suppress plasma testosterone $;^{12}$ expectation of the forthcoming surgery might therefore lower the preoperative testosterone concentrations. Finally, there may be an actual increase in Leydig cell population after vasectomy. Although the results of animal experiments are not consistent, hyperplasia of Leydig cells after vasectomy has been suggested, ${ }^{13}{ }^{14}$ and Gupta et al ${ }^{15}$ recently reported a similar histological change in some humans.

Clearly the endocrine effects of vasectomy remain uncertain, and, although our results are reassuring, long-term prospective studies are essential.

We thank Professor Sir Richard Doll for his advice; Mr D W G
Budd, Mrs Rotha Peers, and staff of the Elliot-Smith Clinic in Oxford and $\mathrm{Mr} \mathrm{J}$ K Monro and staff of the Simon Clinic in Swindon for their co-operation and help. Mr D Hunter, Dr J I Mann, and other colleagues gave valuable help. We are indebted to $\mathrm{Dr} W \mathrm{R}$ Butt and the National Pituitary Agency (USA) for gifts of antigen and antiserum and to Mrs Diana Collinge and Mrs Gale Mead for secretarial work.

\section{References}

1 Sackler, A M, et al, Science, 1973, 179, 293.

2 Nickell, M D, et al, Federation Proceedings, 1974, 33, 531.

3 Kinson, G A, and Layberry, R A, Contraception, 1975, 11, 143.

4 Collins, W P, et al, fournal of Steroid Biochemistry, 1972, 3, 333.

5 Emment, Y, Collins, W P, and Sommerville, I F, Acta Endocrinologica, $1972,69,567$.

${ }^{6}$ Rowe, P H, et al, fournal of Endocrinology, 1974, 61, 63.

7 Rose, R M, et al, fournal of Endocrinology, 1972, 54, 177

${ }^{8}$ Bunge, R G, Investigative Urology, 1972, 10, 9.

- 9 Johnsonbaugh, R E, et al, Fertility and Sterility, 1975, 26, 329.

10 Smith, K D, Chowdhury, M, and Tcholakian, R K, in Control of Male Fertility, ed J J Sciarra, C Markland, and J J Speidel, p 169. Hagerstown, Harper and Row, 1975.

11 Ismail, A A A, and Harkness, R A, Acta Endocrinologica, 1967, 56, 469.

12 Kreuz, L E, Rose, R M, and Jennings, J R Archives of General Psychiatry, 1972, 26, 479 .

13 Easterday, J L, et al, Research Communications in Chemical Pathology and Pharmacology, 1973, 6, 301.

14 Kothari, L K, Mishra, P, and Mishra, R K, American fournal of Surgery, 1973, 126, 84.

15 Gupta, A S, et al, British fournal of Surgery, 1975, 62, 59.

\title{
The retroverted gravid uterus and its effect on the outcome of pregnancy
}

\author{
A R L WEEKES, R D ATLAY, V A BROWN, E C JORDAN，S M MURRAY
}

British Medical fournal, 1976, 1, 622-624

\section{Summary}

Among 1954 pregnant women who booked before the end of the 14th week of gestation the uterus was retroverted in $220(11.2 \%)$. The incidence of bleeding in early pregnancy and spontaneous abortion was significantly higher

\footnotetext{
Department of Obstetrics and Gynaecology, Mill Road Maternity Hospital, Liverpool L6 $2 \mathrm{AH}$

A R L WEEKES, FRCSED, MRCOG, senior registrar

R D ATLAY, MB, MRCOG, consultant

V A BROWN, $\mathrm{MB}, \mathrm{CHB}_{\text {, registrar }}$

New Medical School, University of Liverpool, Liverpool L69 3BX

E C JORDAN, medical student

S M MURRAY, medical student
}

in the retroverted group. Only three patients $(1.4 \%)$ with a retroverted gravid uterus developed acute retention of urine. Patients with retroverted uteri did not have a higher incidence of previous infertility, nor any increase in the incidence of common obstetric abnormalities.

\section{Introduction}

The retroverted gravid uterus is now thought to cause fewer problems than was once believed, and its importance as a contributory factor in infertility and abortion has been the subject of changing opinion..$^{1-3}$ It is no longer thought to be associated with a higher incidence of abortion but this view is largely based on the results of a small series of cases ${ }^{4}$; furthermore, this contention has never been statistically proved. ${ }^{5}$ We sought to clarify whether retroversion of the uterus in early pregnancy was associated with a significantly higher incidence of abortion when compared with pregnancies occurring in women with a normally 
positioned uterus. We also investigated the generally held belief that mobile retroversion of the uterus does not predispose to infertility. The last report on this subject recommended surgical correction of the retroverted uterus in an infertile woman if all other causes of infertility had been excluded. ${ }^{4}$ We also investigated the relation of the retroverted gravid uterus to the outcome of pregnancy as judged by common complications, birth weight, and perinatal mortality, as this has not been reported.

\section{Patients and methods}

The patients studied all attended Mill Road Maternity Hospital, Liverpool, from 1972 to 1974 . All patients were asked at their booking visit for a full obstetric history, and the position and size of the pregnant uterus was recorded in all patients who booked before the end of the 14th week of gestation. Any complication that occurred during the pregnancy along with any other relevant facts and the final outcome were recorded on punch cards. Of the 6798 patients surveyed 1954 patients who booked before the end of the 14th week of gestation were included in the study. They were divided into two groups according to whether the uterus was retroverted (220 patients) or anteverted (1734 patients).

The management of patients in early pregnancy did not differ according to the position of the uterus, and no specific action was taken or advice given to those patients who had a retroverted gravid uterus.

The $\chi^{2}$ test, with Yates's correction, was applied to assess the significance of differences between the two groups.

\section{Results}

Retroversion of the gravid uterus was present in $12.2 \%$ of multigravidae and $9.5 \%$ of primigravidae, with an overall incidence of $11.3 \%$. Gestational age at diagnosis (estimated at booking) in both groups is shown in table I. The proportion of patients in each gestational age group was similar $(P>0 \cdot 1)$.

TABLE I-Gestational age at diagnosis

\begin{tabular}{|c|c|c|c|c|c|c|c|c|c|c|c|}
\hline \multicolumn{2}{|c|}{ Gestational age (weeks): } & 6 & 7 & 8 & 9 & 10 & 11 & 12 & 13 & 14 & Total \\
\hline $\begin{array}{l}\text { Retroverted group } \\
\text { Anteverted group }\end{array}$ & ․ & $\begin{array}{r}6 \\
61\end{array}$ & $\begin{array}{r}4 \\
27\end{array}$ & $\begin{array}{r}40 \\
287\end{array}$ & $\begin{array}{r}27 \\
239\end{array}$ & $\begin{array}{c}62 \\
534\end{array}$ & $\begin{array}{c}23 \\
163\end{array}$ & $\begin{array}{c}33 \\
270\end{array}$ & 19 & $\begin{array}{r}6 \\
35\end{array}$ & $\begin{array}{r}220 \\
1734\end{array}$ \\
\hline & . & 67 & 31 & 327 & 266 & 596 & 186 & 303 & 137 & 41 & 1954 \\
\hline
\end{tabular}

Bleeding in early pregnancy and abortion-The overall incidence of bleeding before the end of the 14th week of gestation was $16.9 \%$, and the incidence was significantly higher in the retroverted group $(25.5 \%)$ than in the anteverted group $(15.9 \%)\left(\chi^{2}=12.1 ; \mathrm{DF}=1\right.$; $\mathbf{P}<0.001)$. The proportion of patients in the retroverted group who actually aborted was also significantly greater than in the anteverted group $\left(\chi^{2}=9.8 ; \mathrm{DF}=1 ; \mathrm{P}<0.01\right.$ ) (table II), but the incidence of abortion in patients who bled was only slightly higher in the retroverted than in the anteverted group $\left(\chi^{2}=0.42 ; \mathrm{DF}=1 ; \mathrm{P}>0.05\right)$. In the retroverted group $74.3 \%$ of abortions occurred after 10 weeks of gestation compared with only $41 \%$ of abortions in the anteverted group (table II) $\left(\chi^{2}=14.06 ; \mathrm{DF}=1 ; \mathrm{P}<0.001\right)$

Obstetric history-The incidence of previous abortion was significantly higher in patients in the retroverted group (table III) $(P<0.05)$ and the parity of patients in this group was also much greater than in the anteverted group $(P<0.001)$.

Previous Infertility - The incidence of both primary and secondary previous infertility in the two groups was similar (table IV).

Complications of pregnancy-There was a slightly higher incidence of hyperemesis gravidarum when the uterus was retroverted (table V), and urinary tract infection before the end of the 14th week was
TABLE III-Numbers of previous abortions before 14th week of gestation and previous pregnancies reaching 28 weeks

\begin{tabular}{|c|c|c|c|c|c|c|c|c|c|}
\hline & & \multicolumn{4}{|c|}{ No of previous abortions } & \multicolumn{4}{|c|}{ No of previous pregnancies } \\
\hline & & 0 & 1 & $\geqslant 2$ & Total & 0 & 1 & $\geqslant 2$ & Total \\
\hline $\begin{array}{l}\text { Retroverted group } \\
\text { Anteverted group }\end{array}$ & $\begin{array}{l}\cdots \\
\cdots\end{array}$ & $\begin{array}{r}166 \\
1408\end{array}$ & $\begin{array}{r}41 \\
266\end{array}$ & $\begin{array}{l}13 \\
60\end{array}$ & $\begin{array}{r}220 \\
1734\end{array}$ & $\begin{array}{r}61 \\
728\end{array}$ & $\begin{array}{r}89 \\
518\end{array}$ & $\begin{array}{r}70 \\
488\end{array}$ & $\begin{array}{r}220 \\
1734\end{array}$ \\
\hline Significance & $\cdots$ & \multicolumn{4}{|c|}{$\chi^{2}=5.28 ; D F=2 ; P<0.05$} & \multicolumn{4}{|c|}{$\chi^{2}=17 \cdot 7 ; \mathrm{DF}=2 ; \mathrm{P}<0.001$} \\
\hline Total & $\ldots$ & 1574 & 307 & 73 & 1954 & 789 & 607 & 558 & 1954 \\
\hline
\end{tabular}

TABLE IV-Previous infertility in both groups

\begin{tabular}{|c|c|c|c|c|c|}
\hline & & Primary & Secondary & Nil & Total \\
\hline $\begin{array}{l}\text { Retroverted group } \\
\text { Anteverted group }\end{array}$ & $\ldots$ & $\frac{0}{26(1.5 \%)}$ & $\begin{array}{r}3(1 \cdot 4 \%) \\
38(2 \cdot 2 \%)\end{array}$ & $\begin{array}{r}217 \\
1670\end{array}$ & $\begin{array}{r}220 \\
1734\end{array}$ \\
\hline Total & $\ldots$ & 26 & 41 & 1887 & 1954 \\
\hline
\end{tabular}

$\mathrm{Chi}^{2}=4 \cdot 05 ;$ d.f. $=2 ; \mathrm{P}>0.1$

TABLE V-Complications of pregnancy in both groups

\begin{tabular}{|c|c|c|c|}
\hline & & Retroverted group & Anteverted group \\
\hline \multicolumn{4}{|c|}{ Complications in first trimester* } \\
\hline $\begin{array}{l}\text { No of patients... } \\
\text { No with hyperemesis gravidarum } \\
\text { No with urinary tract infection }\end{array}$ & $\because$ & $\begin{array}{l}220 \\
10(4 \cdot 5 \%) \\
11(5 \cdot 0 \%)\end{array}$ & $\begin{array}{r}1734 \\
49(2 \cdot 8 \%) \\
156(9 \cdot 0 \%)\end{array}$ \\
\hline \multicolumn{4}{|c|}{ Complications in late pregnancy } \\
\hline $\begin{array}{l}\text { No of patients... } \\
\text { No with ante-partum haemorrhage } \\
\text { No in premature labourt } \\
\text { No with pre-eclampsia } \\
\text { No with small-for-dates infants } \\
\text { Perinatal mortality (and rate } \ddagger \text { ) }\end{array}$ & $\begin{array}{l}\because \\
\therefore \\
\therefore \\
\therefore\end{array}$ & $\begin{array}{l}185 \\
7(3 / 8 \%) \\
11(6 \cdot 0 \%) \\
27(14 \cdot 6 \%) \\
36(19.5 \%) \\
5(14 \text { per } \\
1000)\end{array}$ & $\begin{array}{l}1578 \\
70(4 \cdot 4 \%) \\
76(4 \cdot 8 \%) \\
263(16 \cdot 7 \%) \\
328(20 \cdot 8 \%) \\
29(18 \mathrm{per} \\
1000)\end{array}$ \\
\hline
\end{tabular}

*Before end of 14 th week of gestation

Spontaneous delivery before end of 37th week of gestation.

† Corrected to exclude major congenital abnormalities.

commoner in patients who started pregnancy with an anteverted uterus, but neither of these findings reached significance $(P>0.05)$. Three patients $(1.4 \%)$ with a retroverted gravid uterus developed acute retention of urine during the 12th to 14th week of gestation. The incidence of the other complications was similar in the two groups. The perinatal mortality rate, corrected to exclude major congenital abnormalities, was 14 per 1000 for those patients who had a retroverted uterus and 18 per 1000 for those in whom the uterus was anteverted.

\section{Discussion}

Our results show that in the population studied significantly more patients with a retroverted uterus bled in early pregnancy and actually aborted than in those with anteverted uterus. These differences were most apparent at 10 to 14 weeks of gestation. This increasing rate of abortion with increasing uterine size in the retroverted group in contrast to the anteverted group indicates the possibility of a mechanical aetiology. Nevertheless, patients who bled in early pregnancy had an equal chance of aborting regardless of the position of the uterus. This suggests that, although there seems to be an association between retroversion of the gravid uterus and a higher incidence of abortion, once bleeding has occurred the risk of aborting is similar, irrespective of the position of the uterus.

TABLE II-Bleeding in early pregnancy related to gestational age. Number of abortions is shown in parentheses

\begin{tabular}{|c|c|c|c|c|c|c|c|c|c|c|}
\hline Gestational age (weeks): & 6 & 7 & 8 & 9 & 10 & 11 & 12 & 13 & 14 & Total \\
\hline $\begin{array}{l}\text { Retroverted group } \\
\text { Anteverted group.. }\end{array}$ & $\begin{array}{l}2(1) \\
6(4)\end{array}$ & $\begin{array}{l}0(0) \\
2(1)\end{array}$ & $\begin{array}{c}5(2) \\
51(37)\end{array}$ & $\begin{array}{l}1(1) \\
12(7)\end{array}$ & $\begin{aligned} 8(5) \\
77(43)\end{aligned}$ & $\begin{array}{c}9(6) \\
17(10)\end{array}$ & $\begin{array}{l}14(8) \\
64(35)\end{array}$ & $\begin{array}{l}12(9) \\
27(10)\end{array}$ & $\begin{array}{r}5(3) \\
19(9)\end{array}$ & $\begin{array}{r}56(35) \\
275(156)\end{array}$ \\
\hline Total & $8(5)$ & $2(1)$ & $56(39)$ & $13(8)$ & $85(48)$ & $26(16)$ & $78(43)$ & $39(19)$ & $24(12)$ & $331(191)$ \\
\hline
\end{tabular}


Because some patients would have aborted in very early pregnancy before being seen for booking at the antenatal clinic they were inevitably excluded from this study. Consequently, our results cannot be interpreted as being representative of the relation between abortion and retroversion in very early pregnancy.

Our findings suggest that retention of urine caused by the retroverted gravid uterus is uncommon. The reason for this is not clear, but Jeffcoate ${ }^{b}$ has suggested that it may be related to the fact that now fewer women are seen with a severe degree of pelvic contraction. Our study did not show an association between retroversion of the uterus and a history of previous infertility. On the contrary, the significantly higher incidence of previous pregnancies in the retroverted group is presumptive evidence of an association between increasing parity and a tendency to retroversion of the uterus. The retroverted gravid uterus clearly does not affect the incidence of urinary tract infection, hyperemesis gravidarum, ante-partum haemorrhage, premature labour, or "light-for-dates" babies.

Our findings suggest that a more cautious approach should be adopted in the management of patients with a retroverted gravid uterus. If seen in early pregnancy advice on sleeping posture, avoidance of intercourse, and frequent emptying of the bladder may be given, and they should be seen again before the end of the 14th week of pregnancy to ensure that anteversion has occurred. Bimanual manipulation should not be performed when the pregnant uterus is retroverted, as our results show that these patients are already at risk. To correct manually the retroverted gravid uterus may only increase the risk of abortion, especially if any force is required. This contention can be confirmed only by a prospective random study.

We thank Mr D Prysor-Jones, Professor J M Beazley, and Mr J R Sutherst for allowing us to study their patients. We also thank other members of the staff who helped us to compile the data, and $\mathrm{Mr} \mathrm{C}$ West of the department of biostatistics, University of Liverpool, who kindly helped with the statistical analysis.

\section{References}

1 Brackett, E S, American fournal of Obstetrics and Gynecology, 1948, 55,184. 2 Javert, C T, American fournal of Obstetrics and Gynecology, 1947, 53, 896. ${ }^{3}$ Moir, C, and Myerscough, P, Munro Kerr's Operative Obstetrics, 8th edn, p 457. London, Balliere, Tindall and Cassell, 1971.

${ }^{4}$ Fouracre Barns, H H, British Medical fournal, 1947, 1, 169.

5 Donald, I, Practical Obstetric Problems, 4th edn, p 216. London, LloydLuke, 1969.

${ }^{6}$ Jeffcoate, T N A, Principles of Gynaecology, 3rd edn, p 354. London, Butterworth, 1967.

\title{
Lysozymuria in diabetes
}

\author{
M FARR, E N WARDLE, K WILKINSON
}

British Medical fournal, 1976, 1, 624-625

\section{Summary}

A reversible lysozymuria indicative of proximal tubular damage to the kidney was found in three out of five patients with diabetic ketosis, and a persistent lysozymuria was found in many patients with diabetic nephropathy. There was no relation between lysozymuria and the degree of proteinuria, and lysozymuria was not due to urinary tract infection. The degree of lysozymuria could be used to assess the severity of diabetic nephropathy.

\section{Introduction}

Urinary lysozyme excretion is used as a measure of dysfunction of the proximal tubules of the kidney ${ }^{12}$ because lysozyme, with a molecular weight of 15000 daltons, is normally filtered at the glomeruli and reabsorbed in the proximal tubules. Only if there is a raised serum concentration owing to release from white cells $^{3}$ or damage to the renal tubular epithelium ${ }^{4}$ does excess lysozyme appear in the urine.

The kidney in diabetic nephropathy presents a difficult problem to the renal investigator. Diabetic nephropathy is

\footnotetext{
Department of Medicine, Royal Victoria Infirmary, Newcastle upon Tyne NE1 4LP

M FARR, MB, MRCP, research fellow (now consultant nephrologist, Hull Royal Infirmary, Hull)

E N WARDLE, MD, MRCP, senior registrar (now locum physician, Sunderland General Hospital, Sunderland)

K WILKINSON, technician
}

partly a specific lesion due to basement membrane thickening, as in diffuse intercapillary glomerulosclerosis or the nodular Kimmelstiel-Wilson disease, but there is also arteriosclerosis and atherosclerosis leading to ischaemic damage to the glomeruli and tubules. It is generally accepted that proteinuria, slowly increasing in severity over the years, is the simplest clinical index of nephropathy. Certainly patients with the heaviest proteinuria have the worst prognosis. ${ }^{5}$

We were interested to examine the incidence of lysozymuria in diabetic nephropathy to see whether it could be related to any of the other indices of renal malfunction.

\section{Methods}

Samples of urine and blood were obtained for estimation of serum and urinary lysozyme and serum and urinary creatinine so that we could calculate a lysozyme:creatinine ratio, as described by Barratt and Crawford. ${ }^{2}$ At the same time a 24-hour urine sample was collected for protein estimation. Samples were obtained from 35 patients with diabetic nephropathy, all of whom had had a renal biopsy and a thorough examination of the retina as part of a therapeutic trial; 68 estimations were performed on samples from these 35 patients. Samples were also obtained from 15 patients with chronic pyelonephritis, 45 patients with a variety of types of nephritis, and seven patients with myeloma. Twenty normal volunteers and 20 diabetics without proteinuria also gave samples. We also performed serial studies on five patients with diabetic ketosis until their recovery.

The lysozyme was estimated by our modification ${ }^{6}$ of the method of Harrison. ${ }^{1}$ This was done by using Micrococcus lysodeikticus as substrate (Sigma Ltd) and using as comparison a standard curve with dilutions of lysozyme at concentrations of $10,5,4,3,2$, and $1 \mathrm{mg} / \mathrm{l}$.

\section{Results}

The figure shows the absolute levels of urinary lysozyme in the various groups of patients. A urinary concentration over $2.0 \mathrm{mg} / \mathrm{l}$ was 